\title{
PHYTOCHEMICAL SCREENING, TOTAL PHENOLIC AND FLAVONOIDS CONTENTS AND ANTIOXIDANT ACTIVITIES OF CITRULLUS COLOCYNTHIS L. AND CANNABIS SATIVA L.
}

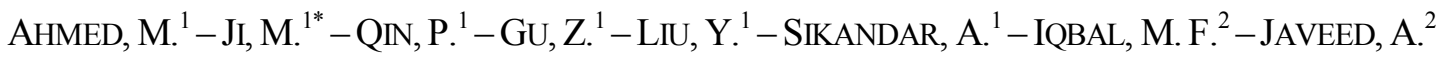 \\ ${ }^{1}$ College of Plant Protection, Shenyang Agricultural University No. 120 Dongling Road, \\ Shenyang, 110866 Liaoning, China \\ ${ }^{2}$ College of Biosciences and Biotechnology, Shenyang Agricultural University \\ No. 120 Dongling Road, Shenyang, 110866 Liaoning, China \\ *Corresponding author \\ e-mail: jimingshan@163.com; phone:+86-24-8848-7148; fax: +86-24-8834-2315
}

(Received $16^{\text {th }}$ Feb 2019 ; accepted $8^{\text {th }}$ Apr 2019)

\begin{abstract}
Citrullus colocynthis L. and Cannabis sativa L. are well known herbs for their curative value and farming applications. Thus, extraction was performed to examine yield, total phenolic, flavonoids content and antioxidant activities for farming exertions. Qualitative analyses were conducted to scrutinize alkaloids, glycosides, terpenoids, flavonoids, flavones, steroids, tannins, phenols, saponins and quantitative analysis for total phenolic and flavonoids content was assessed by Folin-Ciocalteu and aluminium chloride colourimetric method respectively, while antioxidant activities was assessed by using 1, 1-Diphenyl-1-picrylhydrazyl. Results showed that distilled water afforded the maximum extract yield followed by methanol and ethanol thus, coefficient of determination $\left(R^{2}\right)$ of extract yield present a positive correlation compared to root mean square error (RMSE). Phytoconstituents except terpenoids from C. sativa and C. colocynthis leaves were reported while, in contrast, steroids, tannins and phenols were absent in $C$. colocynthis roots. The methanol derived maximum phenolic contents from $C$. sativa and C. colocynthis leaves were 36.42 and $37.69 \mathrm{mg}$ gallic acid equivalent GAE/g respectively. However, total flavonoids registered from C. sativa leaves and C. colocynthis leaves and roots were 59.03, 50.58 and $43.32 \mathrm{mg}$ quercetin equivalent $\mathrm{QE} / \mathrm{g}$ respectively. Interestingly, C. colocynthis leaves produced the highest flavonoids $119.63 \mathrm{mg} \mathrm{QE} / \mathrm{g}$ using ethyl acetate extract. DPPH inhibition (\%) was high in acetone 55.57, hexane 45.98 and distilled water $35.5 \%$ from C. sativa, C. colocynthis leaves and roots respectively. Our findings suggest that studied plants contain phytochemicals, reasonable quantity of phenol and flavonoids content confer to the potential antioxidant activity responsible for insecticidal properties as safer alternatives of synthetic pesticides.
\end{abstract}

Keywords: solvent extraction, biochemical analysis, DPPH inhibition \%, insecticidal agents

\section{Introduction}

Plants are a God-given treasure to human beings; they produce a variety of secondary metabolites, i.e., alkaloids, flavonoids, steroids, glycosides, terpenoids, tannins, saponins, quinine and phenols (Jung et al., 2009) and have the best curative potential of pharmaceutical medicines, biocides and biopesticides (Edeoga et al., 2005; Wells et al., 2009). Plant-produced phytochemicals perform distinctive functions in agriculture, veterinary, and pharmaceutical industries (Vasu et al., 2009).

Several plants are used as herbal medicines and in agriculture farming, including Citrullus colocynthis and Cannabis sativa. C. colocynthis, locally known as Tumba, is viny herbaceous plant that grows in desert or sandy soils, inhabitant to North Africa and is scattered in northern Africa, eastward Sahara, Morocco, Egypt, Sudan, Iran, Afghanistan, Pakistan, India and other tropical areas (Dane et al., 2007; Pravin et al., 2013). It belongs to the family Cucurbitaceae has, gained attention as a natural botanical 
insecticide; its insecticidal activity has been evaluated against several insect pests' species (Soam et al., 2013). Moreover, extract obtained by dichloromethane from $C$. Colocynthis showed $98.4 \%$ mortality against Culex quinquefasciatus at $100 \mathrm{ppm}$ concentration and $\mathrm{LC}_{50}$ and $\mathrm{LC}_{90}$ value were 19.26 ppm and $84.84 \mathrm{ppm}$ respectively after $24 \mathrm{~h}$ of exposure period (Arivoli et al., 2015). Dimetry et al., (2007) documented that $C$. colocynthis formulations are effective biopesticides against stored grain pest like adults of Callosobruchus maculatus. Similarly, aqueous extract from various parts of this plant extensively reduced the population of Rhopalosiphum padi (Asiry, 2015). The ethanolic extract from C. colocynthis exhibited the insecticidal effect against Aphis craccivora and this insecticidal potential is due to the presence of alkaloids, glycosides and saponins (Torkey et al., 2009). It has antifeedants, deterrent, growth-regulating and infertility properties against insects (Seenivasan et al., 2004) and familiar in the traditional medicine and used as purgative, anti-inflammatory, cathartic and pain relieving properties (Mehrzadi et al., 2016; Memon et al., 2003; Shi et al., 2014)

Cannabis is another paramount annual weedy and dioceous plant belongs to family Cannabaceae. Historically, it appears to have been cultivated in Northern China since 4000 BC (Mabberley, 2008). Cannabis is used as a pest repellent and has been grown as a companion crop to kill several insects, fungi, weeds and nematodes. Its extracts have the ability to repel or kill insects, mites, and microorganisms and can be used as allelochemicals. Cannabis leaves have great potential against pests (McPartland, 1997) and these insecticidal properties of plants can be found in their secondary metabolites. For example, crude extract from Chenopodium ficifolium and Jatropha curcas exhibits aphicidal activity, and alkaloids from Corydalis turtschaninovii tubers and Macleaya cordata seeds harbour insecticidal potential (Abdoul Habou et al., 2011; Le Dang et al., 2010; Park et al., 2011; Rashid et al., 2013). The essential oil of Cannabis has demonstrated antimicrobial activity (Nissen et al., 2010; Novak et al., 2001) while, essential oil from Nepalese origin of $C$. sativa was evaluated for cytotoxic, larvicidal and insecticidal activity, and was found as relatively non-toxic (Satyal and Setzer, 2014).

The main bioactive components i.e. flavonoids, alkaloids, terpenoids and phenols from plant origin show strong insecticidal activity. Benelli et al. (2018) reported that essential oil obtained from fresh inflorescence of $C$. sativa dominated by monoterpenes and sesquiterpenes showed strong toxic effects against $M$. domestica at the rate of $43.3 \mu \mathrm{g} /$ adult and $M$. persicae with $\mathrm{LC}_{50}$ of $3.5 \mathrm{ml} / 1$, moderately toxic against $S$. littoralis larvae at the rate of $152.3 \mu \mathrm{g} /$ larva while least toxic against $C$. quinquefasciatus larvae with $\mathrm{LC}_{50}$ of $252.5 \mathrm{ml} / \mathrm{l}$. It contains pesticidal properties however, tetrahydrocannabinol (THC) is the prime constituent and sixty six other cannabinoids are reported including cannabidiol (CBD) and cannabinol (CBN) showing different effects (Fusar-Poli et al., 2009). Moreover, Pellati et al. (2018) analyzed the bioactive components from inflorescences of $C$. sativa (hemp) by means of innovative HPLC and GC methods coupled with GC-MS and GC-FID. Analysis showed the abundance of cannabidiol (CBD) and Cannabidiolic acid (CBDA) while, $\beta$-caryophyllene and $\beta$-myrcene were the major terpenes.

Plants are also a source of cheap antioxidant substitutes; they have the ability to scavenge free radicals, avoid the reaction transmission and hence prevent humans from their damage (Moure et al., 2001). Phenolic compounds, flavonoids and terpenes collected from natural plant resources have potential free radical scavenger activity (Mathew and Abraham, 2006) and are omnipresent groups of plant secondary metabolites (Singh et al., 2007). 
The phytochemical extraction mechanism is important for obtaining better extract yield both qualitatively and quantitatively and scientists have studied the importance of $C$. colocynthis and $C$. sativa as a medicinal, insecticidal and antibacterial agent, but existing knowledge and research presented by different authors is limited to use of few solvents for extraction, extract properties as well as qualitative, quantitative analysis and antioxidants properties are not properly investigated in such a comprehensive way. Although, selected plants belong to different families and also harvested from different locations but it is worth noted that selected plants are potential source of phytochemicals and antioxidants responsible for insecticidal activities. Thus, at present extensive studies have been conducted on qualitative and quantitative extract estimations to identify different phytochemicals responsible for insecticidal potential and to determine the best extraction solvent with maximum phenolic and flavonoid contents and antioxidant activities using seven different solvents from $C$. sativa (leaves) and $C$. colocynthis (leaves and roots) collected from China and Pakistan respectively over the years 20172018.

\section{Materials and methods}

\section{Plant material collection}

Citrullus colocynthis (Colocynth), locally known as Tumba, and Cannabis indica formerly called as Cannabis sativa sub-species indica (Hemp) were the study plants. Young leaves and roots of Colocynthis were collected from (Bahawalnagar) a desert area of Punjab Province, Pakistan from March-April 2018 (Fig. la and 1b), while hemp leaves were collected from different locations of Shenyang, Liaoning Province, China from August-September 2017 (Fig. 1c). In total ten samples of each plant were collected belongs to same area and same species. Collected samples of colocynthis and hemp were then mixed together separately to obtain bulk volume of each plant. Botanical identification of colocynthis as C. colocynthis was performed at Department of Botany Pir Mehar Ali Shah Arid Agriculture University Rawalpindi (PMAS, AAUR) Pakistan, while hemp was identified as C. sativa by Professor Ji Mingshan, Department of Pesticides Science, College of Plant Protection, Shenyang Agriculture University, Shenyang Liaoning China.

\section{Sample preparation}

Leaves and roots were washed, dried under shade at room temperature, crushed into a fine powder by using an electric blender, sieved through $100 \mu \mathrm{m}$ mesh and finally $1 \mathrm{~kg}$ of each plant sample was obtained and stored in airtight glass jars at $4{ }^{\circ} \mathrm{C}$.

\section{Solvent extraction}

Different solvents were selected with varying polarity level to extract crude material by cold extraction method which was simple, easy and safe for elution of bioactive compounds along with pigments (Handa et al., 2008). For each solvent extraction of each bulk plant material, $100 \mathrm{~g}$ of powdered sample was taken in a $1000 \mathrm{ml}$ conical flask separately and extracted with $400 \mathrm{ml}$ of respective solvent (Mondal, 2015). Extraction was performed at room temperature for $72 \mathrm{~h}$ (Mojab et al., 2010; Senguttuvan et al., 2014). The extraction process was repeated thrice to ensure that all polar and non-polar materials were eluted completely (Waiganjo et al., 2013). Filtered the contents, and 


$$
\text { - } 6964 \text { - }
$$

concentrated to reduce the volume on a rotary evaporator (Buchi Switzerland R-210). The concentrated filtrate was dried in a fume cupboard at $25^{\circ} \mathrm{C}$. Solvent-free extract was placed in a stoppered glass bottle and stored at $4^{\circ} \mathrm{C}$ for further use. The physical properties of each extract (colour, stickiness and appearance) were recorded visually.

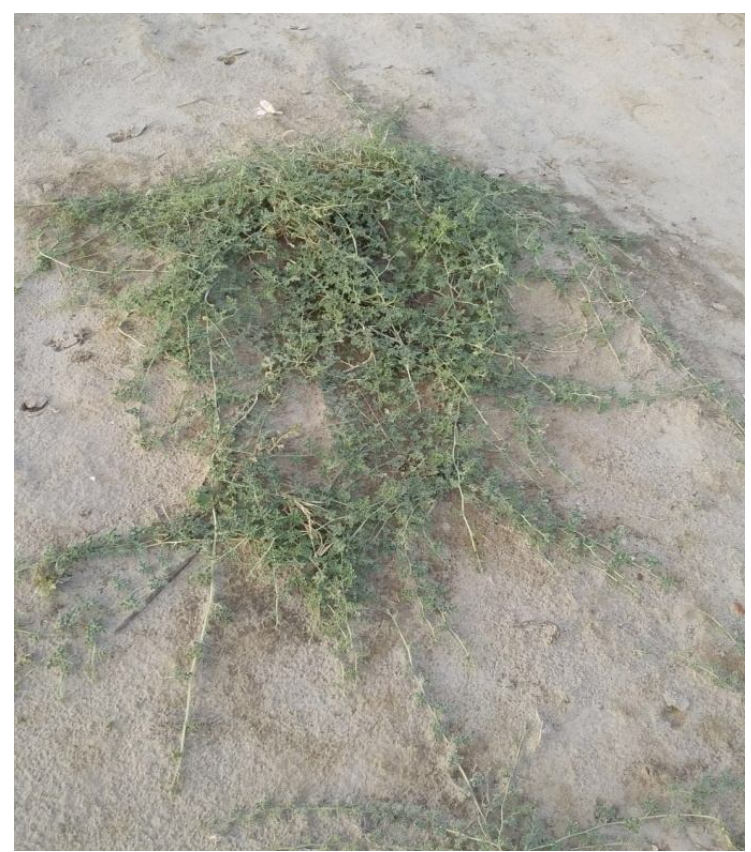

a

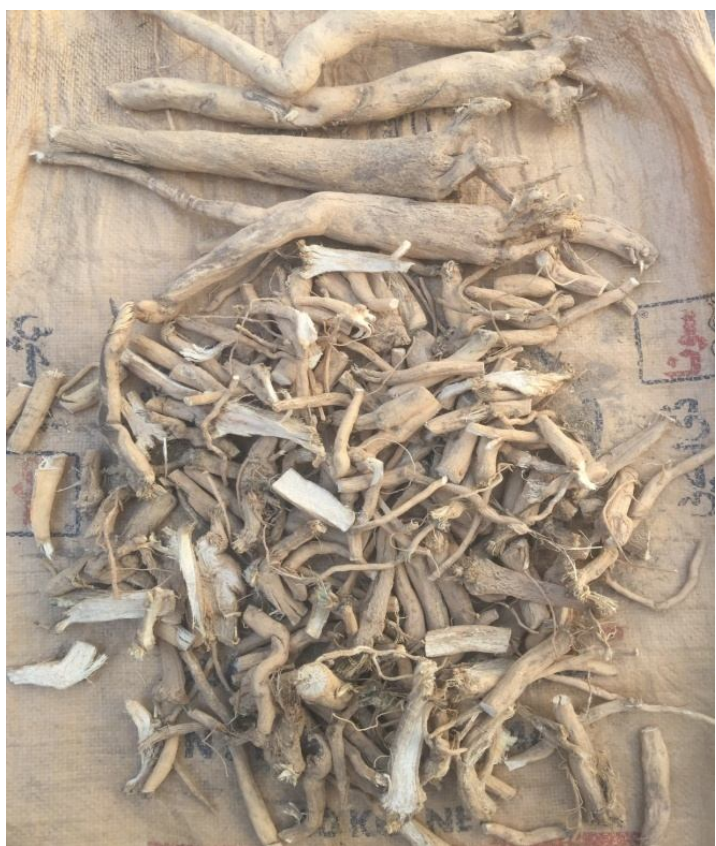

b

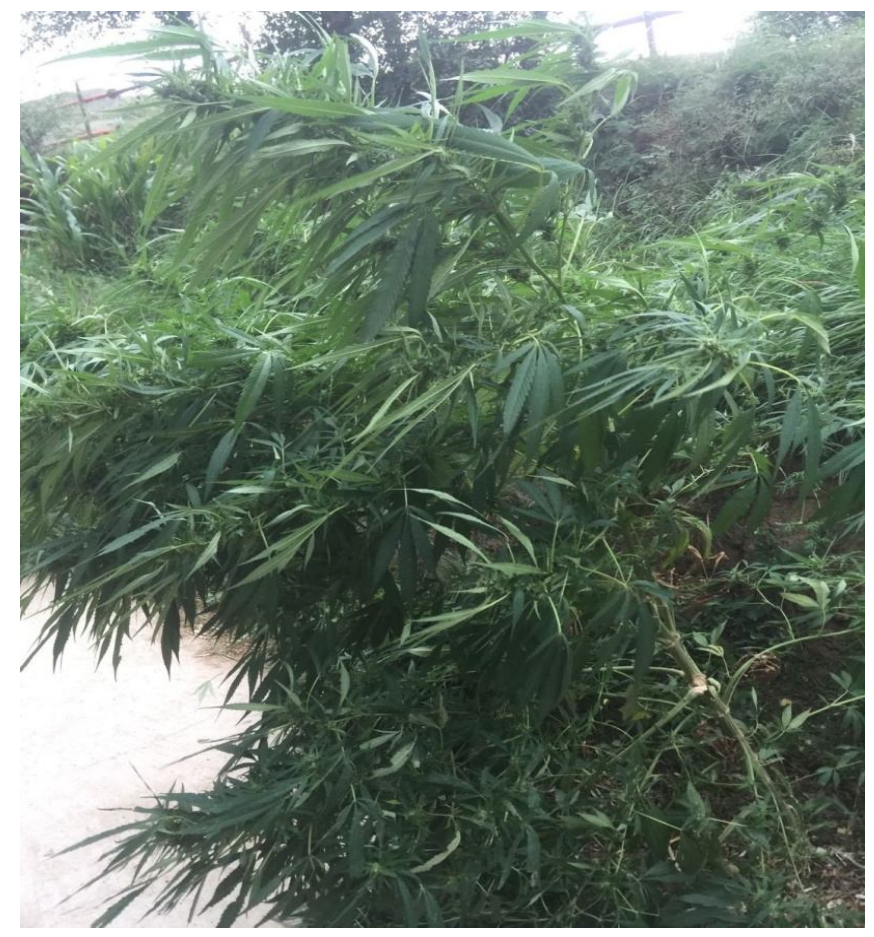

C

Figure 1. a C. colocynthis plant. b C. colocynthis (roots). c C. sativa plant 


\section{Aqueous extraction}

A total of $100 \mathrm{~g}$ powdered plant samples was extracted at room temperature with $400 \mathrm{ml}$ of distilled water for $72 \mathrm{~h}$. The rest of the procedure was same as for solvent extraction.

\section{Calculation of extract yield (g)}

The extract yield was calculated for each solvent from the respective plant material and stored at $4{ }^{\circ} \mathrm{C}$ for further studies.

\section{Model validations}

The relationship was used to develop the model for yield and for the comparison of coefficient of determination $\left(R^{2}\right)$ values with root mean square error (RMSE). The coefficient of determination $R^{2}$ and RMSE represent the standard deviation of the residuals (prediction errors). Residuals are the measures that how the values are far from the regression lines where the data points were. This measure also told us how condensed the data were around the line of best fitness and model validity (Hossain et al., 2017). Performance of the model in the crude extract yield was evaluated by using RMSE. In the experiment with observations ' $n$ ', RMSE was calculated by identity Equation 1 (Debaeke et al., 1997).

$$
\text { RMSE }=\sqrt{1 / n \times \sum_{j=1}^{n}\left(\left(\text { Yield }_{m e s}-\text { Yield }_{\text {sim }}\right)^{2}\right.}
$$

\section{Qualitative phytochemical analysis}

Phytochemical screening tests were performed to evaluate the presence or absence of phytoconstituents in C. colocynthis and C. sativa extracts using standard methods.

\section{Test for alkaloids}

For the estimation of alkaloids, $0.5 \mathrm{ml}$ of each solvent extract was allowed to dry and $2 \mathrm{ml}$ of $2 \%$ hydrochloric acid $(\mathrm{HCl})$ was added to the residue in the test tube for $15 \mathrm{~min}$ in a water bath at $100^{\circ} \mathrm{C}$. After cooling, the mixture was filtered and divided into two equal portions. A few drops of Mayer's reagent were added to one portion, while a few drops of Dragendoff's reagent were added to the other portion. Turbidity or the presence of a yellow precipitate confirm the presence of alkaloids (Siddiqui and Ali, 1997).

\section{Test for glycosides}

The presence of glycosides was evaluated by adding $2 \mathrm{ml}$ distilled water and $2 \mathrm{ml}$ $5 \%$ ferric chloride $\left(\mathrm{FeCl}_{3}\right)$ into $2 \mathrm{ml}$ extract. The mixture was heated for $15 \mathrm{~min}$ in a water bath and then allowed to cool. Next, $1 \mathrm{ml}$ benzene was added to the mixture and subjected to settle for 1 min after shaking. Next, 4 to 5 drops of concentrated ammonia $\left(\mathrm{NH}_{3}\right)$ was added. A pink or red colour indicates the presence of glycosides (Siddiqui and Ali, 1997; Siddiqui et al., 2009; Sofowora, 1993). 


\section{Test for terpenoids and steroids}

The presence of terpenoids and steroids was determined by a previously described method (Kantamreddi and Lakshmi; Siddiqui and Ali, 1997) with slight modifications. Briefly, $0.5 \mathrm{~g}$ of solvent-free extract was added in $2 \mathrm{ml}$ chloroform and then filtered. The filtrate was placed on ice; addition of $2 \mathrm{ml}$ of acetic acid and then a few drops of concentrated sulfuric acid $\left(\mathrm{H}_{2} \mathrm{SO}_{4}\right)$ was carefully applied to the inner sides of the test tubes. The emergence of a pink or pinkish brown colour/ring indicates the terpenoids existence, while a blue or bluish green colour for steroids presence and the combination of pink and blue/bluish green colours confirmed the presence of both terpenoids and steroids.

\section{Test for flavonoids and flavones}

Two millilitres of diluted sodium hydroxide $(\mathrm{NaOH})$ was added to the 3 ml extract solution, which turned the solution into a yellow colour. The solution was treated with $1 \mathrm{ml} 5 \mathrm{~N}$ hydrochloric acid $(\mathrm{HCl})$, which turned the solution colourless, indicate flavonoids, and an orange colour indicate flavones (Siddiqui and Ali, 1997; Siddiqui et al., 2009; Sofowora, 1993).

\section{Test for tannins}

For the estimation of tannins, $1 \mathrm{ml}$ distilled water and ferric chloride $\left(\mathrm{FeCl}_{3}\right) 1-2$ drops were added to $0.5 \mathrm{ml}$ plant extract. The appearance of a blue and green/black colour indicates gallic and catecholic tannin, respectively (Iyengar, 1995).

\section{Test for phenols}

To detect phenols, $1 \mathrm{ml}$ of extract solution was added to $2 \mathrm{ml}$ distilled water and a few drops of $10 \%$ ferric chloride $\left(\mathrm{FeCl}_{3}\right)$. The appearance of a green or blue colour is the indication of phenols presence. Next, $0.50 \mathrm{~g}$ of plant extract was added and allowed to dissolve in distilled water and then $3 \mathrm{ml}$ of $10 \%$ lead acetate was added. The presence of phenolic compounds was confirmed by the appearance of white precipitation (Trease et al., 2003).

\section{Test for saponins}

One gram of solvent-free extract was diluted with $20 \mathrm{ml}$ of distilled water and shacked vigorously. The formation of a foam layer $(1 \mathrm{~cm})$ indicates the presence of saponins (Siddiqui and Ali, 1997).

\section{Quantitative phytochemical analysis}

\section{Determination of total phenolic content (TPC)}

The total phenols present in the crude extract of $C$. colocynthis and $C$. sativa was calculated by the Folin-Ciocalteu reagent method, with slight modifications. Briefly, $1 \mathrm{ml}$ plant extract $\left(1 \mathrm{mgml}^{-1}\right.$ of solvent) was added to $2.5 \mathrm{ml}$ of $10 \%$ Folin-Ciocalteu reagent (1:1) and $2 \mathrm{ml}$ of $2 \%$ sodium carbonate $\left(\mathrm{Na}_{2} \mathrm{CO}_{3}\right)$. The consequential mixture was allowed to stand for incubation for $15 \mathrm{~min}$ at room temperature in the dark. The solution was then transferred to a 96-well ELISA plate to measure the absorbance at $765 \mathrm{~nm}$ using an absorbance microplate reader (SpectraMax 190, manufactured in 
China; designed in USA). All test calculations were carried out in triplicate. A standard calibration curve was constructed using gallic acid $\left(1 \mathrm{mgml}^{-1}\right)$. The results were calculated from the standard curve obtained by using different concentrations of gallic acid $\left(1,0.50,0.25,0.10,0.05,0.02,0.01\right.$ and $\left.0 \mathrm{mgml}^{-1}\right)$ and are expressed as gallic acid equivalent (GAE) $\mathrm{mgg}^{-1}$ of extracted compounds (Aiyegoro and Okoh, 2010).

\section{Determination of total flavonoid content (TFC)}

The amount of total flavonoids in the crude extract of $C$. colocynthis and C. sativa was estimated by a colourimetric method using aluminium trichloride $\left(\mathrm{AlCl}_{3}\right)$ and sodium hydroxide $(\mathrm{NaOH})$. Briefly, $1 \mathrm{ml}$ of extract $\left(1 \mathrm{mgml}^{-1}\right.$ of solvent $)$ was added to $3 \mathrm{ml}$ methanol, $0.2 \mathrm{ml} 10 \%$ aluminium chloride, $0.2 \mathrm{ml} 1 \mathrm{M}$ potassium acetate $\left(\mathrm{CH}_{3} \mathrm{COOK}\right)$ and $5.6 \mathrm{ml}$ distilled water. The resulting mixture was incubated at room temperature in the dark for $30 \mathrm{~min}$. The assay was performed at $420 \mathrm{~nm}$ in a 96-well ELISA plate. Quercetin was used as the standard $\left(1 \mathrm{mgml}^{-1}\right)$ and a standard curve was obtained using different concentrations of quercetin $(1,0.50,0.25,0.10,0.05,0.02,0.01$ and $0 \mathrm{mgml}^{-1}$ ). Results are expressed as quercetin equivalent (QE) $\mathrm{mgg}^{-1}$ of extracted compounds (Aiyegoro and Okoh, 2010). All test determinations were carried out in triplicate.

\section{Determination of DPPH radical scavenging activity}

The antioxidant activities of crude extracts of $C$. colocynthis and $C$. sativa were measured on the basis of the scavenging activities of the stable 1,1-diphenyl-1picrylhydrazyl (DPPH) radical (Yu et al., 2003). Briefly, $0.5 \mathrm{ml}$ of each respective extract was added to a sample cavity containing $3.5 \mathrm{ml}$ of freshly prepared methanol

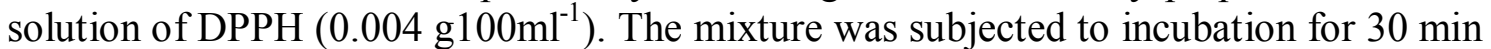
at room temperature in the darkness and absorbance was calculated at $517 \mathrm{~nm}$. The percent inhibition of DPPH (I \%) was calculated from the decrease of absorbance by Equation 2. A lower absorbance value represents higher free radical scavenging activity (Zhao et al., 2008).

$$
I \%=\frac{A_{\text {blank }}-A_{\text {gample }}}{A_{\text {blami }}} \times 100
$$

Whereas $A_{\text {blank }}=$ absorbance of control; $A_{\text {gample }}=$ absorbance of samples.

\section{Statistical analysis}

Data were analysed statistically by one-way analysis of variance (ANOVA) in Duncan's multiple range test (DMRT) and values are represented as the mean \pm standard deviation, with $\mathrm{P}=0.05$ indicating a significant difference. Analyses were conducted by using SPSS 13.0 (Inc.) software while graph was constructed by sigma Plot software.

\section{Results}

\section{Potential solvent for extraction}

Extraction was performed on C. colocynthis leaves and roots and on C. sativa leaves using different solvents and distilled water. Extract yields (g) was calculated and 
presented in Figure 2 while extract properties were described in Table 1. Figure 2 and Table 1 showed that using distilled water, $C$. sativa leaves produced a significant yield $(11.688 \mathrm{~g})$, with the physical properties of dark brown colour, non sticky and dry solid, followed by methanol (9.412 g), black shiny, more sticky, and ethanol (6.296 g), blackish and shiny.

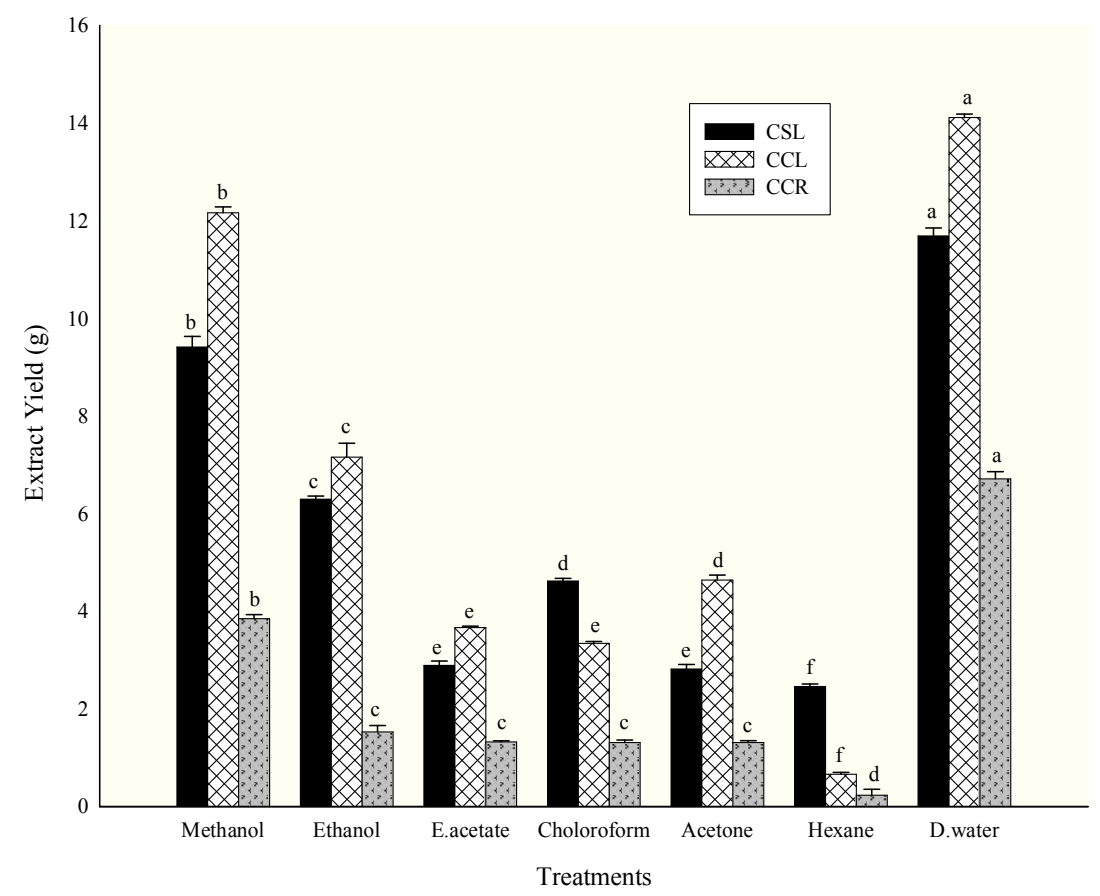

Figure 2. Extract yield (g) of C. sativa leaves (CSL) and C. colocynthis leaves (CCL) and roots (CCR) by using different solvents. Highest yield produced by D. water and methanol while lower yield produced by hexane from CCL, CSL and CCR respectively. Data corresponding to treatments labelled with different letters are significantly different (Duncan's multiple range test DMRT at $P \leq 0.05)$; the error bars represent standard of the means

Table 1. Properties of CSL, CCL and CCR crude extract

\begin{tabular}{|c|c|c|c|c|c|c|c|c|c|}
\hline \multirow{2}{*}{$\begin{array}{c}\text { Solvents } \\
\text { extract }\end{array}$} & \multicolumn{3}{|c|}{ CSL } & \multicolumn{3}{|c|}{ CCL } & \multicolumn{3}{|c|}{ CCR } \\
\hline & Colour & Stickiness & Appearance & Colour & Stickiness & Appearance & Colour & Stickiness & Appearance \\
\hline Methanol & $\begin{array}{l}\text { Black, } \\
\text { shiny }\end{array}$ & $\begin{array}{l}\text { More } \\
\text { sticky }\end{array}$ & $\begin{array}{c}\text { Slowly } \\
\text { flowable }\end{array}$ & $\begin{array}{c}\text { Greenish } \\
\text { black, shiny }\end{array}$ & Sticky & Oily, flowable & Brown & Non-sticky & $\begin{array}{l}\text { Semi solid, } \\
\text { non-oily }\end{array}$ \\
\hline Ethanol & \begin{tabular}{|c|}
$\begin{array}{c}\text { Blackish, } \\
\text { shiny }\end{array}$ \\
\end{tabular} & $\begin{array}{l}\text { More } \\
\text { sticky }\end{array}$ & $\begin{array}{c}\text { Slowly } \\
\text { flowable }\end{array}$ & $\begin{array}{c}\text { Brownish } \\
\text { black, shiny }\end{array}$ & Sticky & Oily, flowable & $\begin{array}{c}\text { Yellowish } \\
\text { brown }\end{array}$ & Non-sticky & Dry, waxy \\
\hline E. acetate & Blackish & Sticky & $\begin{array}{c}\text { Oily, } \\
\text { flowable }\end{array}$ & Blackish & Sticky & Oily & $\begin{array}{c}\text { Dark } \\
\text { brown }\end{array}$ & Less sticky & Dry, non-oily \\
\hline Chloroform & $\begin{array}{c}\text { Brownish } \\
\text { black }\end{array}$ & $\begin{array}{l}\text { Less } \\
\text { sticky }\end{array}$ & $\begin{array}{c}\text { Less oily, } \\
\text { non-flowable }\end{array}$ & $\begin{array}{l}\text { Black, } \\
\text { Shiny }\end{array}$ & Less sticky & \begin{tabular}{|c|} 
Less oily, \\
non-flowable
\end{tabular} & Brown & Less sticky & $\begin{array}{c}\text { Semi-solid, } \\
\text { non-flowable }\end{array}$ \\
\hline Acetone & $\begin{array}{c}\text { Brownish } \\
\text { black }\end{array}$ & sticky & $\begin{array}{c}\text { Oily, } \\
\text { flowable }\end{array}$ & $\begin{array}{c}\text { Greenish } \\
\text { black }\end{array}$ & Sticky & Oily & Yellow & Non-sticky & $\begin{array}{l}\text { Dry, Non- } \\
\text { flowable }\end{array}$ \\
\hline Hexane & Yellowish & $\begin{array}{l}\text { Less } \\
\text { sticky }\end{array}$ & $\begin{array}{c}\text { Non-oily, } \\
\text { non flowable }\end{array}$ & $\begin{array}{l}\text { Yellowish } \\
\text { brown }\end{array}$ & Less sticky & $\begin{array}{c}\text { Non-oily, non } \\
\text { flowable }\end{array}$ & $\begin{array}{l}\text { Light } \\
\text { yellow }\end{array}$ & Non-sticky & $\begin{array}{l}\text { Semi-solid, } \\
\text { non-flowable }\end{array}$ \\
\hline $\begin{array}{l}\text { Distilled } \\
\text { water }\end{array}$ & $\begin{array}{l}\text { Dark } \\
\text { brown }\end{array}$ & $\begin{array}{l}\text { Non- } \\
\text { sticky }\end{array}$ & Dry solid & Dark brown & Less sticky & Less oily & Brown & Less sticky & $\begin{array}{l}\text { Dry, non- } \\
\text { flowable }\end{array}$ \\
\hline
\end{tabular}

CSL (C. sativa leaves), CCL (C. colocynthis leaves), CCR (C. colocynthis roots) 
C. colocynthis leaves produced significant yield (14.115 g) using distilled water, with the physical properties of dark brown colour, less sticky followed by methanol (12.161 g), greenish shiny black and sticky, and ethanol (7.158 g), brownish black shiny and sticky.

C. colocynthis roots recorded a significantly high yield by distilled water $(6.712 \mathrm{~g})$, with the physical properties of dark brown colour and less sticky, followed by methanol $(3.848 \mathrm{~g})$, with the physical properties of greenish black, oily and ethanol $(1.528 \mathrm{~g})$, yellowish brown and waxy. However, the yields recorded by ethyl acetate $(1.324 \mathrm{~g})$, chloroform and acetone $(1.312 \mathrm{~g})$ were non significant $(\mathrm{P}>0.05)$ to each other but differed significantly compared with all other treatments.

\section{Model validation}

The model validation performance for extract yield in response to $C$. sativa leaves and $C$. colocynthis leaves and roots is listed in Table 2. The $C$. sativa leaves extract exerted significant $(\mathrm{P}<0.001)$ effects on the aqueous extract compared to all other treatments. The extract yield revealed that $R^{2}$ values of $C$. sativa using methanol, ethanol, ethyl acetate, chloroform, acetone, hexane and distilled water were 0.99, 0.93, $0.92,0.87,0.87,0.93$ and 0.82 respectively showed better performances compared to RMSE. Data on the extract yield for colocynthis leaves were statistically analysed and recorded as significant $(\mathrm{P}<0.05)$ when obtained by methanol, with $R^{2}$ values of 0.99 , $0.80,0.98,0.99,0.81,0.99$ and 0.91 . These extract yields for C. colocynthis roots were highly significant $(\mathrm{P}<0.01)$ when obtained by distilled water and methanol compared to all other treatments. However, $R^{2}$ values of $C$. colocynthis roots $0.89,0.84,0.95,0.94$, $0.99,0.94$ and 0.92 showed the best curvature and best fit to the obtained data.

Table 2. Regression model for phytochemical screening of cumulative extract yield

\begin{tabular}{c|c|c|c|c|c|c}
\hline \multirow{2}{*}{ Solvent extract } & \multicolumn{2}{|c|}{ CSL } & \multicolumn{2}{c|}{ CCL } & \multicolumn{2}{c}{ CCR } \\
\cline { 2 - 7 } & $R^{2}$ & $R M S E$ & $R^{2}$ & $R M S E$ & $R^{2}$ & $R M S E$ \\
\hline Methanol & 0.99 & 0.045266 & 0.99 & 0.0041231 & 0.89 & 0.0360786 \\
Ethanol & 0.93 & 0.588661 & 0.79 & 0.2680105 & 0.84 & 0.0989949 \\
Ethyl acetate & 0.92 & 0.075688 & 0.97 & 0.0245221 & 0.95 & 0.0070711 \\
Chloroform & 0.87 & 0.009556 & 0.99 & 0.0311127 & 0.94 & 0.0141421 \\
Acetone & 0.87 & 0.024042 & 0.81 & 0.1209201 & 0.99 & 0.0023804 \\
Hexane & 0.93 & 0.024338 & 0.99 & 0.0028284 & 0.94 & 0.1075546 \\
Distilled water & 0.82 & 0.308299 & 0.91 & 0.0268886 & 0.92 & 0.0287171 \\
\hline
\end{tabular}

$R^{2}$ (Correlation coefficient), RMSE (Root mean square error), CSL (C. sativa leaves); CCL $(C$. colocynthis leaves); CCR (C. colocynthis roots)

\section{Qualitative phytochemical analysis}

Tests for phytochemical screening were conducted to determine the presence of bioactive compounds, namely, alkaloids, glycosides, terpenoids, flavonoids, flavones, steroids, tannins, phenols and saponins from C. colocynthis and C. sativa (Tables 3, 4 and $5)$. However the confirmation of a bioactive compound was referred as high presence $(++)$ on strong resemblance; moderate presence $(+)$ on medium or weak and $(-)$ with no resemblance, appearance or change of colour of the reactive solution. The detection of alkaloids in the solvent extract was confirmed by turbidity or the emergence of a yellow 
precipitate. The glycosides presence was confirmed by the appearance of a red or pink colouration in the reaction mixture. Positive results for terpenoids were confirmed by $C$. colocynthis roots, with the appearance of a pink or pinkish brown colour. Flavonoids and flavones were recorded by the transformation of the mixture from yellow to colourless and orange, respectively. The presence of tannins was confirmed by the appearance of a blue colour for gallic tannin and green/black for catecholic tannin. Blue or green colour in the reaction mixture indicated the presence of phenols while, foaming character in extract solution is important for the confirmation of saponins.

Phytochemical analysis indicated a high presence of steroids in chloroform and hexane extracts and a moderate presence in most other solvent extracts from $C$. sativa leaves except for distilled water extract (Table 3). Terpenoids were absent in all extracts. Alkaloids were absent in ethyl acetate, chloroform and distilled water extracts, while glycosides were present in all of these extracts except for hexane. Moreover, flavonoids were highly present in methanol and ethanol but moderately present in acetone and hexane. Flavones were present in acetone, as well as hexane and distilled water extracts. Saponins were present in chloroform, hexane and Distilled water extracts. However, gallic tannins were absent in all extracts, while catecholic tannins were absent in acetone, hexane and distilled water extracts. Phytochemical screening showed that phenols were present in methanol, ethyl acetate, ethanol and distilled water extracts.

Table 3. Qualitative phytochemical screening of C. sativa leaves crude extract

\begin{tabular}{|c|c|c|c|c|c|c|c|c|c|c|}
\hline \multirow[b]{2}{*}{ Solvents extract } & \multirow[b]{2}{*}{ 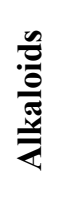 } & \multirow[b]{2}{*}{ 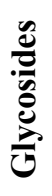 } & \multirow[b]{2}{*}{$\begin{array}{l}\frac{n}{0} \\
\frac{0}{0} \\
\frac{0}{0} \\
\end{array}$} & \multirow[b]{2}{*}{ 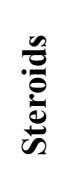 } & \multirow[b]{2}{*}{ 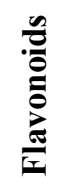 } & \multirow[b]{2}{*}{ 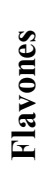 } & \multicolumn{2}{|c|}{ Tannins } & \multirow[b]{2}{*}{$\begin{array}{l}\frac{n}{O} \\
\frac{E}{E}\end{array}$} & \multirow[b]{2}{*}{ 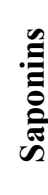 } \\
\hline & & & & & & & 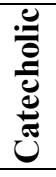 & ڤّ & & \\
\hline Methanol & + & - & - & + & ++ & - & + & - & + & - \\
\hline Ethanol & + & - & - & + & ++ & - & + & - & + & - \\
\hline Ethyl acetate & - & + & - & + & - & - & + & - & + & - \\
\hline Chloroform & - & + & - & ++ & - & - & - & - & - & + \\
\hline Acetone & + & - & - & + & + & + & + & - & - & - \\
\hline Hexane & + & + & - & ++ & + & + & - & - & - & + \\
\hline Distilled water & - & - & - & - & - & + & - & - & + & + \\
\hline
\end{tabular}

++ high presence, + moderate presence, -absence

Table 4. Qualitative phytochemical screening of C. colocynthis leaves crude extract

\begin{tabular}{|c|c|c|c|c|c|c|c|c|c|c|}
\hline \multirow[b]{2}{*}{ Solvents extract } & \multirow[b]{2}{*}{ 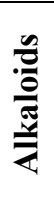 } & \multirow[b]{2}{*}{ 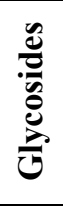 } & \multirow[b]{2}{*}{$\begin{array}{l}\frac{0}{0} \\
\frac{0}{0} \\
\frac{0}{0} \\
\stackrel{0}{0}\end{array}$} & \multirow[b]{2}{*}{ 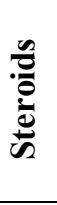 } & \multirow[b]{2}{*}{ 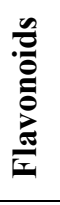 } & \multirow[b]{2}{*}{$\underset{E}{\stackrel{E}{E}}$} & \multicolumn{2}{|c|}{ Tannins } & \multirow[b]{2}{*}{$\frac{\frac{n}{0}}{\stackrel{0}{E}}$} & \multirow[b]{2}{*}{ 象 } \\
\hline & & & & & & & 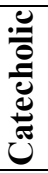 & 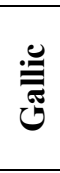 & & \\
\hline Methanol & + & - & - & + & ++ & - & + & - & ++ & - \\
\hline Ethanol & - & + & - & + & ++ & - & + & - & + & - \\
\hline Ethyl acetate & - & + & - & + & ++ & + & - & ++ & ++ & - \\
\hline Chloroform & - & ++ & - & + & + & + & - & - & - & - \\
\hline Acetone & - & - & - & + & - & - & + & - & + & - \\
\hline Hexane & - & ++ & - & + & + & + & - & - & - & - \\
\hline distilled water & - & - & - & - & - & - & - & - & + & + \\
\hline
\end{tabular}

++high presence, + moderate presence, -absence 
Table 5. Qualitative phytochemical screening of C. colocynthis roots crude extract

\begin{tabular}{|c|c|c|c|c|c|c|c|c|c|c|}
\hline \multirow[b]{2}{*}{ Solvents extract } & \multirow[b]{2}{*}{ 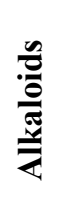 } & \multirow[b]{2}{*}{$\begin{array}{l}\frac{0}{0} \\
\frac{0}{0} \\
\frac{0}{0} \\
\frac{0}{0}\end{array}$} & \multirow[b]{2}{*}{$\begin{array}{l}\frac{a}{0} \\
\frac{0}{0} \\
\stackrel{0}{0} \\
\stackrel{0}{0}\end{array}$} & \multirow[b]{2}{*}{ } & \multirow[b]{2}{*}{ 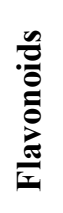 } & \multirow[b]{2}{*}{ 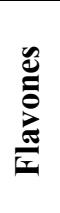 } & \multicolumn{2}{|c|}{ Tannins } & \multirow[b]{2}{*}{$\frac{n}{\stackrel{0}{E}}$} & \multirow[b]{2}{*}{ 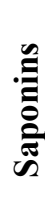 } \\
\hline & & & & & & & 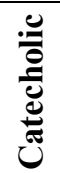 & ڤ̆ & & \\
\hline Methanol & - & - & - & - & ++ & + & - & - & - & + \\
\hline Ethanol & - & - & ++ & - & ++ & + & - & - & - & - \\
\hline Ethyl Acetate & - & - & + & - & + & - & - & - & - & + \\
\hline Chloroform & - & - & + & - & + & - & - & - & - & - \\
\hline Acetone & + & - & + & - & + & - & - & - & - & - \\
\hline Hexane & - & - & - & - & + & - & - & - & - & - \\
\hline Distilled water & - & + & - & - & - & - & - & - & - & + \\
\hline
\end{tabular}

++ high presence, + moderate presence, -absence

C. colocynthis leaves showed a moderate presence of phenols by methanol, ethanol, ethyl acetate, acetone and distilled water but an absence in other extracts. However, a high glycoside presence was recorded by chloroform and hexane, with a moderate presence by ethanol and ethyl acetate (Table 4). Alkaloids were absent in all extracts except for methanol. Terpenoids were absent in all extracts. A high presence of flavonoids was recorded in methanol, ethanol and ethyl acetate, while a moderate presence of flavonoids was recorded in chloroform and hexane extracts. Flavones were present in ethyl acetate, chloroform and hexane extracts. Steroids were present in all extracts except for distilled water. Tannins were present in methanol, ethanol, ethyl acetate and acetone extracts, while saponins were present only in distilled water extract.

As shown in (Table 5), the phytochemical analysis of C. colocynthis roots demonstrated the presence of glycosides and alkaloid in distilled water and acetone extract, respectively. Steroids, tannins and phenols were absent in all extracts. However, terpenoids showed a high presence in ethanol and a moderate presence in ethyl acetate, chloroform and acetone extracts but an absence in methanol and distilled water. Although the presence of flavonoids was recorded in all extracts except for distilled water extract, flavones were recorded by methanol and ethanol only. The presence of saponins was recorded by methanol, ethyl acetate and distilled water extract.

\section{Quantitative analysis}

\section{Total phenolic content (TPC)}

The total phenolic contents of various extracts from $C$. colocynthis leaves and roots and $C$. sativa leaves varied slightly. The maximum and minimum phenolic contents from $C$. sativa leaves were recorded by methanol and distilled water $(36.42 \pm 1.905$ and $29.98 \pm 0.56 \mathrm{mg}$ gallic acid equivalent $\mathrm{GAE} / \mathrm{g}$, respectively). However, minimum phenols recorded by ethyl acetate and ethanol were $(12.16 \pm 0.977$ and $2.70 \pm 0.109 \mathrm{mg}$ $\mathrm{GAE} / \mathrm{g}$ ) respectively while other solvents recorded negative phenols (Table 6). Methanol and distilled water extracts from $C$. colocynthis leaves showed a higher phenolic content of $37.69 \pm 0.35$ and $37.25 \pm 0.83 \mathrm{mg}$ GAE$/ \mathrm{g}$, respectively, followed by acetone, ethanol and ethyl acetate $(24.08 \pm 1.78,22.82 \pm 0.37$ and $5.73 \pm 0.56 \mathrm{mg} \mathrm{GAE} / \mathrm{g}$, respectively). However, C. colocynthis roots showed negative results for phenols. 
Table 6. Total phenolic content (TPC) from CSL, CCL and CCR

\begin{tabular}{c|c|c|c}
\hline \multirow{2}{*}{ Solvents extract } & \multicolumn{3}{|c}{ Total phenolic contents mg GAE/g } \\
\cline { 2 - 4 } & CSL & CCL & CCR \\
\hline Methanol & $36.42 \pm 1.905^{\mathrm{a}}$ & $37.69 \pm 0.35^{\mathrm{a}}$ & - \\
Ethanol & $2.70 \pm 0.109^{\mathrm{d}}$ & $22.82 \pm 0.37^{\mathrm{b}}$ & - \\
Ethyl acetate & $12.16 \pm 0.977^{\mathrm{c}}$ & $5.73 \pm 0.561^{\mathrm{c}}$ & - \\
Chloroform & - & - & - \\
Acetone & - & $24.08 \pm 1.78^{\mathrm{b}}$ & - \\
Hexane & - & - & - \\
Distilled water & $29.98 \pm 0.56^{\mathrm{b}}$ & $37.25 \pm 0.83^{\mathrm{a}}$ & - \\
\hline
\end{tabular}

Results are presented as the mean values \pm standard deviation. Same letters within a column indicate that mean values are not significantly different $(\mathrm{P}>0.05)$ according to Duncan's multiple range test; CSL (C. sativa leaves); CCL (C. colocynthis leaves); CCR (C. colocynthis roots)

\section{Total flavonoid content (TFC)}

The total flavonoid content was high in the methanol and ethanol extracts of $C$. sativa leaves (59.03 \pm 1.31 and $56.00 \pm 1.85 \mathrm{mg}$ quercetin equivalent $\mathrm{QE} / \mathrm{g}$, respectively), followed by hexane and acetone $(17.35 \pm 0.43$ and $12.08 \pm 0.62 \mathrm{mg} \mathrm{QE} / \mathrm{g}$, respectively) (Table 7). Thus, ethyl acetate extract from $C$. colocynthis leaves produced the highest flavonoid content (119.63 $\mathrm{mg} \mathrm{QE} / \mathrm{g})$, followed by ethanol, methanol and hexane (54.84 $\pm 0.90,50.58 \pm 0.85$ and $22.7 \pm 1.14 \mathrm{mg} \mathrm{QE} / \mathrm{g}$, respectively). However, the lowest flavonoid content was detected by chloroform $(1.73 \pm 0.09 \mathrm{mg} \mathrm{QE} / \mathrm{g})$. The total flavonoid content of $C$. colocynthis roots by methanol and ethanol was the highest $(43.32 \pm 0.33$ and $42.34 \pm 0.23 \mathrm{mg} \mathrm{QE} / \mathrm{g}$, respectively), followed by ethyl acetate and acetone (28.93 and $8.86 \mathrm{mg} \mathrm{QE} / \mathrm{g}$, respectively). Chloroform and hexane extracts showed the lowest flavonoid content $(2.23 \pm 0.18$ and $1.23 \pm 0.09 \mathrm{mg} \mathrm{QE} / \mathrm{g}$, respectively).

Table 7. Total flavonoids content (TFC) from CSL, CCL and CCR

\begin{tabular}{c|c|c|c}
\hline \multirow{2}{*}{ Solvents extract } & \multicolumn{3}{|c}{ Total flavonoid contents mg QE/g } \\
\cline { 2 - 4 } & CSL & CCL & \multicolumn{1}{c}{ CCR } \\
\hline Methanol & $59.03 \pm 1.312^{\mathrm{a}}$ & $50.58 \pm 0.85^{\mathrm{c}}$ & $43.32 \pm 0.33^{\mathrm{a}}$ \\
Ethanol & $56.001 \pm 1.85^{\mathrm{b}}$ & $54.84 \pm 0.9^{\mathrm{b}}$ & $42.34 \pm 0.235^{\mathrm{b}}$ \\
Ethyl acetate & - & $119.63 \pm 0.31^{\mathrm{a}}$ & $28.93 \pm 0.19^{\mathrm{c}}$ \\
Chloroform & - & $1.7318 \pm 0.09^{\mathrm{e}}$ & $2.233 \pm 0.182^{\mathrm{e}}$ \\
Acetone & $12.086 \pm 0.62^{\mathrm{d}}$ & - & $8.863 \pm 0.154^{\mathrm{d}}$ \\
Hexane & $17.35 \pm 0.43^{\mathrm{c}}$ & $22.7 \pm 1.14^{\mathrm{d}}$ & $1.2343 \pm 0.094^{\mathrm{f}}$ \\
Distilled water & - & - & - \\
\hline
\end{tabular}

Results are presented as the mean values \pm standard deviation. Same letters within a column indicate that mean values are not significantly different $(\mathrm{P}>0.05)$ according to Duncan's multiple range test; CSL (C. sativa leaves); CCL (C. colocynthis leaves); CCR (C. colocynthis roots) 


\section{DPPH radical scavenging activity}

DDPH is a stable and free radical which is easily dissolved in methanol showed characteristics colour absorption at $517 \mathrm{~nm}$ using spectrophotometer. Free radicals are scavenged by antioxidant molecules due to donation of hydrogen molecules and the colour of DPPH assay solution changed to light yellow colour causing reduction of absorbance. To determine free radical scavenging activity, the DPPH radicals are widely used. Data on the 1,1-Diphenyl-1-picrylhydrazyl (DPPH) scavenging activity of free radical of $C$. sativa leaves and $C$. colocynthis leaves and roots are presented in (Table 8).

Table 8. DPPH radical scavenging activity from CSL, CCL and CCR

\begin{tabular}{c|c|c|c}
\hline \multirow{2}{*}{ Solvents extract } & \multicolumn{3}{|c}{ DPPH Inhibition (\%) } \\
\cline { 2 - 4 } & CSL & CCL & CCR \\
\hline Methanol & $49.5 \pm 0.7^{\mathrm{b}}$ & $30.65 \pm 1.07^{\mathrm{e}}$ & $23.63 \pm 0.68^{\mathrm{f}}$ \\
Ethanol & $54.1 \pm 0.2^{\mathrm{a}}$ & $36.52 \pm 0.62^{\mathrm{c}}$ & $33.83 \pm 0.351^{\mathrm{b}}$ \\
Ethyl acetate & $46 \pm 1^{\mathrm{c}}$ & $27.66 \pm 1.53^{\mathrm{f}}$ & $27.65 \pm 0.01^{\mathrm{e}}$ \\
Chloroform & $40.6 \pm 0.8^{\mathrm{d}}$ & $29.64 \pm 0.05^{\mathrm{e}}$ & $30.69 \pm 0.8^{\mathrm{c}}$ \\
Acetone & $55.57 \pm 1.2^{\mathrm{a}}$ & $33.5 \pm 0.51^{\mathrm{d}}$ & $30.97 \pm 0.98^{\mathrm{c}}$ \\
Hexane & $41.7 \pm 0.5^{\mathrm{d}}$ & $45.98 \pm 0.14^{\mathrm{a}}$ & $29.12 \pm 0.7^{\mathrm{d}}$ \\
Distilled water & $34.2 \pm 1.1^{\mathrm{e}}$ & $39.8 \pm 0.21^{\mathrm{b}}$ & $35.5 \pm 0.16^{\mathrm{a}}$ \\
\hline
\end{tabular}

Results are presented as the mean values \pm standard deviation. Same letters within a column indicate that mean values are not significantly different $(\mathrm{P}>0.05)$ according to Duncan's multiple range test; CSL (C. sativa leaves); CCL (C. colocynthis leaves); CCR (C. colocynthis roots)

For $C$. sativa leaves, DPPH inhibition (\%) by distilled water and acetone ranged from $34.2 \pm 1.10$ to $55.57 \pm 1.20 \%$. For $C$. colocynthis leaves, the DPPH inhibition (\%) of chloroform and hexane extract ranged from $29.64 \pm 0.05$ to $45.98 \pm 0.14 \%$. However, the DPPH scavenging activity of $C$. colocynthis roots for methanol and distilled water ranged from $23.63 \pm 0.68$ to $35.5 \pm 0.16 \%$. It was also noted that all extracts of $C$. sativa and $C$. colocynthis showed varying levels of DPPH radical scavenging activity.

\section{Discussion}

The comparative extraction of crude extracts from $C$. colocynthis and C. sativa demonstrated that using methanol as an extraction solvent resulted in the maximum extract yield followed by ethanol, chloroform, ethyl acetate, acetone and hexane. However, using distilled water instead of organic solvent produced the maximum yield. Our results are consistent with (Awang et al., 2016; Markom et al., 2007; Pin et al. 2009) who reported that the highest extract yield was obtained by using water for extraction from M. malabathricum leaves, Phyllanthus niruri and Piper betel. Among the polarity-based solvents, methanol produced the maximum yield, followed by ethanol. Similar results were demonstrated by (Dhawan and Gupta, 2017; Paulsamy and Jeeshna, 2011) that methanol produced the maximum extract yield from Datura metel and $H$. radicata leaves.

The extract yield revealed that $R^{2}$ relationship of $C$. sativa ranging from $0.82-0.99$ for distilled water and methanol have strong positive correlation compared to RMSE 0.308- 
0.045 which showed better performance of model fitness. The trendline regression $\mathrm{R}^{2}$ for $C$. colocynthis leaves were 0.99 for methanol, chloroform and hexane showed strong correlation while for $C$. colocynthis roots 0.99 by acetone recorded the best curvature and fitness of the model with recorded data.

The extraction of secondary metabolites highly depends on the extraction technique, solvent used and the chemical properties of the compounds. The analysis of C. Sativa leaf extracts showed the presence of alkaloids, glycosides, steroids, flavonoids, flavones, tannins, phenols and saponins and the absence of terpenoids. Relevant results were presented by Audu et al. (2014), who reported the presence of phytochemicals except for saponins and phenols in the leaves and roots of $C$. sativa. Various bioactive compounds such as flavonoids, alkaloids, glycosides, carbohydrates and essential oils have been documented previously from $C$. colocynthis by Wasylikowa and Van der Veen (2004). These isolated compounds like Flavonoids, isovitexin, isosaponarin and isoorientin 3'-O-methyl ether are revealed as significant antioxidants (Kumar et al., 2008). The results described by Najafi et al. (2010) on the phytochemical constituents from $C$. colocynthis leaves showed the presence of alkaloids, glycosides, tannins, flavonoids and saponins, consistent with our results. However, the results from our study are strongly correlated with Uma and Sekar (2014), who reported the presence of secondary metabolites in C. colocynthis leaves and roots. Singh (2010) reported the presence of bioactive compounds but no saponins or anthraquinones were reported from C. colocynthis roots.

C. colocynthis contains mostly flavonoids, while Ziziphus spina-christi contains the highest phenolic content (Tawfik et al., 2015). Phenols are biologically active compounds that are potent antioxidants with free radical scavenging behaviour. Haniyeh et al. (2016) reported that phenolic and flavonoid contents from the methanol extract of C. Colocynthis leaves were 79.78 and $45.46 \mu \mathrm{gml}^{-1}$, respectively. Similar findings were also observed herein, with phenolic and flavonoid contents of 37.69 and $50.58 \mathrm{mgg}^{-1}$, respectively. However, phenols were absent in all extracts of $C$. colocynthis roots. Moreover, Rizvi et al. (2018) reported the presence of polyphenol content from $C$. colocynthis leaves using different polarity solvent, methanol, ethyl acetate, chloroform,

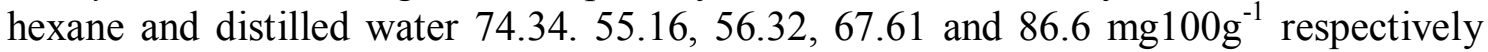
which is relevant to our findings for phenol content from $C$. colocynthis leaves. Maximum phenol and flavonoids content recorded by methanol from C. sativa 36.42 and $59.03 \mathrm{mgg}^{-1}$ are consistent with Abd-Alla and Haggag (2013) who reported total phenol and flavonoid contents of $9.62 \mathrm{mgg}^{-1}$ and $1.9 \mathrm{mgg}^{-1}$, respectively, with $14.5 \%$ antioxidant activity from the leaf extract of $C$. sativa.

The results from different studies have revealed that phenols, flavonoid content and antioxidant properties differ in different parts of $C$. colocynthis. Plants are an active source of valuable chemicals and other bioactive compounds that contain pesticidal activity against numerous insect pests (Koul and Walia, 2009). Salama and Al Rabiah (2015) reported the presence of phenol, flavonoid and antioxidant activities from twenty medicinal plants, with maximum phenol and flavonoid contents of $224.49 \mathrm{mg} / 100 \mathrm{~g}$ and

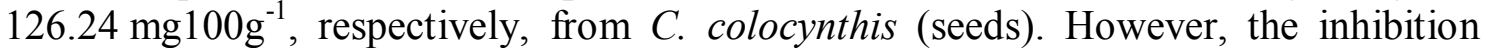
percent in the ethanol extracts of roots and leaves was 56.8-67.2\% and 5.97-6.42 $\mu \mathrm{gml}^{-1}$, respectively. Among the ethanol extracts, leaves had the highest free radical inhibition activity in $C$. colocynthis $\left(\mathrm{IC}_{50}=2.97,67.2 \%\right.$ ) (Hussain et al., 2013). Our findings also demonstrated that inhibition (\%) in the ethanolic extract from leaves and roots was 36.52 and $33.83 \%$, respectively. However, there are variations in antioxidants contained 
by $C$. sativa and $C$. colocynthis among different solvents extract. Additionally, Eddouks et al. (2002) reported that methanolic extract of $C$. colocynthis seed exhibited highest inhibition 79.4 and $72.4 \%$ by using 1, 1-diphenyl-2-picrylhydrazyl (DPPH). Rathanavel and Arasu (2014) documented that Colocynth contains several phytoconstituents, such as flavonoids, alkaloids, glycosides, tannins saponins, carbohydrates and essential oils responsible for insecticidal activities.

Results from phytochemical analysis of $C$. sativa and $C$. colocynthis are characterized by the presence of various phytochemicals along with phenols, flavonoids content and antioxidant activity. However, data on previous studies for extraction and comparing the extract yield using different solvent, qualitative and quantitative analysis, antioxidant activity and use of bioactive compounds as alternative of synthetic chemicals from these plants is limited. Also synthetic agents in present era liberate maximum residues in environment and naturally grown population which is burning issue in current agro-ecosystem. So the study was conducted to examine extract yields using seven different solvents by solvent extraction method, to observe physical properties of extract, scrutinize bioactive compounds and to quantify total phenol, flavonoids contents and to asses' antioxidant activities by DPPH radical scavenging from crude extracts of study plants. Also solvents extract from $C$. colocynthis roots, yield calculation and physical properties were studied for the first time in such a comprehensive way.

\section{Conclusion}

The results demonstrated that crude extracts obtained by using different solvents from $C$. colocynthis and $C$. sativa possess biological compounds, such as terpenoids, glycosides, alkaloids, flavonoids, flavones, steroids, tannins, phenols and saponins. Owing to extraction, distilled water afforded the maximum yield followed by methanol with high phenol and flavonoid content. Hence, the studied plants are a rich source of phytocompounds, conferring them interesting antioxidant activity and supporting their use as potential insecticidal agents which are safe for environment and biodiversity. However, comprehensive research is needed to identify additional solvents and techniques for the extraction, isolation, purification and identification of active ingredient responsible for insecticidal activities.

Acknowledgements. The financial support provided by National Key Research \& Development Programme of China (2016YFD0200500).

Conflict of interests. The authors have declared no conflict of interests.

\section{REFERENCES}

[1] Abd-Alla, M., Haggag, W. M. (2013): Use of some plant essential oils as post-harvest botanical fungicides in the management of anthracnose disease of mango fruits (Mangi feraindica L.) caused by Colletotrichum gloeosporioides (penz). - International Journal of Agriculture and Forestry 3: 1-6.

[2] Abdoul Habou, Z., Haougui, A., Mergeai, G., Haubruge, E., Toudou, A., Verheggen, F. (2011): Insecticidal effect of Jatropha curcas oil on the aphid Aphis fabae (Hemiptera: Aphididae) and on the main insect pests associated with cowpeas (Vigna unguiculata) in Niger. - Tropicultura 29: 225-229. 
[3] Aiyegoro, O. A., Okoh, A. I. (2010): Preliminary phytochemical screening and in vitro antioxidant activities of the aqueous extract of Helichrysum longifolium DC. - BMC Complementary and Alternative Medicine 10: 21.

[4] Asiry, K. A. (2015): Aphidicidal activity of different aqueous extracts of bitter apple Citrullus colocynthis (L.) against the bird cherry-oat aphid, Rhopalosiphum padi (L.) (Homoptera: Aphididae) under laboratory conditions. - J. Anim. Plant. Sci. 25: 456-462.

[5] Audu, B. S., Ofojekwu, P. C., Ujah, A., Ajima, M. N. (2014): Phytochemical, proximate composition, amino acid profile and characterization of Marijuana (Cannabis sativa L.). J Phytopharm 3: 35-43.

[6] Awang, M. A., Aziz, R., Sarmidi, M. R., Abdullah, L. C., Yong, P. K., Musa, N. F. (2016): Comparison of different solvents on the extraction of Melastoma malabathricum leaves using Soxhlet extraction method. - Der Pharmacia Lettre 8: 153-157.

[7] Benelli, G., Pavela, R., Petrelli, R., Cappellacci, L., Santini, G., Fiorini, D., Sut, S., Dall'Acqua, S., Canale, A., Maggi, F. (2018): The essential oil from industrial hemp (Cannabis sativa L.) by-products as an effective tool for insect pest management in organic crops. - Industrial Crops and Products 122: 308-315.

[8] Dane, F., Liu, J., Zhang, C. (2007): Phylogeography of the bitter apple, Citrullus colocynthis. - Genetic Resources and Crop Evolution 54: 327-336.

[9] Debaeke, P., Caussanel, J. P., Kiniry, J. R., Kafiz, B., Mondragon, G. (1997): Modelling crop: weed interactions in wheat with ALMANAC. - Weed Research 37: 325-341.

[10] Dhawan, D., Gupta, J. (2017): Comparison of different solvents for phytochemical extraction potential from Datura metel plant leaves. - International Journal of Biological Chemistry 11: 17-22.

[11] Dimetry, N. Z., El-Gengaihi, S., El-Salam, A. A. (2007): Protection of stored cowpea from Callosobruchus maculatus (F.) attack by some plant extract formulations in different storage sacks. - Herba Polonica 53: 71-84.

[12] Eddouks, M., Maghrani, M., Lemhadri, A., Ouahidi, M.-L., Jouad, H. (2002): Ethnopharmacological survey of medicinal plants used for the treatment of diabetes mellitus, hypertension and cardiac diseases in the south-east region of Morocco (Tafilalet). - Journal of Ethnopharmacology 82: 97-103.

[13] Edeoga, H. O., Okwu, D. E., Mbaebie, B. O. (2005): Phytochemical constituents of some Nigerian medicinal plants. - African Journal of Biotechnology 4: 685-688.

[14] Fusar-Poli, P., Crippa, J. A., Bhattacharyya, S., Borgwardt, S. J., Allen, P., MartinSantos, R., Seal, M., Surguladze, S. A., O'Carrol, C., Atakan, Z. (2009): Distinct effects of $\Delta 9$-tetrahydrocannabinol and cannabidiol on neural activation during emotional processing. - Archives of General Psychiatry 66: 95-105.

[15] Handa, S., Khanuja, S., Longo, G., Rakesh, D. (2008): Extraction Technologies for Medicinal and Aromatic Plants. - Earth, Environmental and Marine Sciences and Technologies, International Centre for Science and High Technology, Trieste.

[16] Haniyeh, R., Hamzeh, A., Ahmad, G. (2016): Antioxidant properties and flavonoidsphenolic content of citrullus colocynthis (L.) schrad growing in Khuzestan, Iran. Bimonthly Journal of Hormozgan University of Medical Sciences 20: 33-38.

[17] Torkey, H.M., Abou-Yousef, H.M., Abdel Azeiz, A.Z., Hoda, Farid, E.A. (2009): Insecticidal effect of cucurbitacin E glycoside isolated from Citrullus colocynthis against Aphis craccivora. - Australian Journal of Basic and Applied Sciences 3: 4060-4066.

[18] Hossain, S. A. A. M., Wang, L., Chen, T., Li, Z. (2017): Leaf area index assessment for tomato and cucumber growing period under different water treatments. - Plant, Soil and Environment 63: 461-467.

[19] Hussain, A. I., Rathore, H. A., Sattar, M. Z. A., Chatha, S. A. S., ud din Ahmad, F., Ahmad, A., Johns, E. J. (2013): Phenolic profile and antioxidant activity of various extracts from Citrullus colocynthis (L.) from the Pakistani flora. - Industrial Crops and Products 45: 416-422. 
[20] Iyengar, M. A., 1995: Study of Crude Drugs. 8th Ed. - Manipal Power Press, Manipal, India.

[21] Arivoli, S., Raveen, R., Samuel, T. (2015): Larvicidal activity of Citrullus colocynthis (1.) Schrad (Cucurbitaceae) isolated fractions against Aedes aegypti (1.), Anopheles stephensi (1.) and Culex quinquefasciatus say (Diptera: Culicidae). - Indian Journal of Applied Research 5: 97-101.

[22] Jung, H. W., Tschaplinski, T. J., Wang, L., Glazebrook, J., Greenberg, J. T. (2009): Priming in systemic plant immunity. - Science 324: 89-91.

[23] Kantamreddi, V. S. S. N., Lakshmi, Y. N., Kasapu, V. V. V. S. (2010): Preliminary phytochemical analysis of some important indian plant species. - International Journal of Pharma and Bio Sciences 1: B-358 ref.12.

[24] Koul, O., Walia, S. (2009): Comparing impacts of plant extracts and pure allelochemicals and implications for pest control. - CAB Reviews: Perspectives in Agriculture, Veterinary Science, Nutrition and Natural Resources 4: 1-30.

[25] Kumar, S., Kumar, D., Saroha, K., Singh, N., Vashishta, B. (2008): Antioxidant and free radical scavenging potential of Citrullus colocynthis (L.) Schrad. methanolic fruit extract. - Acta Pharmaceutica 58: 215-220.

[26] Le Dang, Q., Lee, G. Y., Choi, Y. H., Choi, G. J., Jang, K. S., Park, M. S., Soh, H. S., Han, Y. H., Lim, C. H., Kim, J.-C. (2010): Insecticidal activities of crude extracts and phospholipids from Chenopodium ficifolium against melon and cotton aphid, Aphis gossypii. - Crop Protection 29: 1124-1129.

[27] Mabberley, D. (2008): Mabberley's Plant Book. 3rd Ed. - Cambridge University Press, Cambridge.

[28] Markom, M., Hasan, M., Daud, W. R. W., Singh, H., Jahim, J. M. (2007): Extraction of hydrolysable tannins from Phyllanthus niruri Linn.: Effects of solvents and extraction methods. - Separation and Purification Technology 52: 487-496.

[29] Mathew, S., Abraham, T. E. (2006): In vitro antioxidant activity and scavenging effects of Cinnamomum verum leaf extract assayed by different methodologies. - Food and Chemical Toxicology 44: 198-206.

[30] McPartland, J. M. (1997): Cannabis as repellent and pesticide. - Journal of the International Hemp Association 4: 89-94.

[31] Mehrzadi, S., Shojaii, A., Pur, S. A., Motevalian, M. (2016): Anticonvulsant activity of hydroalcoholic extract of Citrullus colocynthis fruit: involvement of benzodiazepine and opioid receptors. - Journal of Evidence-Based Complementary \& Alternative Medicine 21: NP31-NP35.

[32] Memon, U., Brohi, A. H., Ahmed, S. W., Azhar, I., Bano, H. (2003): Antibacterial screening of Citrullus colocynthis. - Pakistan journal of pharmaceutical sciences 16: 1-6.

[33] Mojab, F., Kamalinejad, M., Ghaderi, N., Vahidipour, H. R. (2010): Phytochemical screening of some species of Iranian plants. - Iranian Journal of Pharmaceutical Research: 77-82.

[34] Mondal, K. K. (2015): Potential investigation of anti-inflammatory activity and phytochemical investigations of ethanolic extract of Glycosmis pentaphylla Leaves. American Journal of Biomedical Research 3: 6-8.

[35] Moure, A., Cruz, J. M., Franco, D., Domínguez, J. M., Sineiro, J., Domínguez, H., Núñez, M. a. J., Parajó, J. C. (2001): Natural antioxidants from residual sources. - Food Chemistry 72: 145-171.

[36] Najafi, S., Sanadgol, N., Nejad, B. S., Beiragi, M. A., Sanadgol, E. (2010): Phytochemical screening and antibacterial activity of Citrullus colocynthis (Linn.) Schrad against Staphylococcus aureus. - Journal of Medicinal Plants Research 4: 2321-2325.

[37] Nissen, L., Zatta, A., Stefanini, I., Grandi, S., Sgorbati, B., Biavati, B., Monti, A. (2010): Characterization and antimicrobial activity of essential oils of industrial hemp varieties (Cannabis sativa L.). - Fitoterapia 81: 413-419. 
[38] Novak, J., Zitterl $\square$ Eglseer, K., Deans, S. G., Franz, C. M. (2001): Essential oils of different cultivars of Cannabis sativa L. and their antimicrobial activity. - Flavour and Fragrance Journal 16: 259-262.

[39] Park, H.-J., Baek, M.-Y., Cho, J.-G., Seo, K.-H., Lee, G.-Y., Moon, S.-J., Ahn, E.-M., Baek, N.-I. (2011): Insecticidal alkaloids on aphids from Corydalis turtschaninovii tubers. - Journal of the Korean Society for Applied Biological Chemistry 54: 345-352.

[40] Paulsamy, S., Jeeshna, M. V. (2011): Preliminary phytochemistry and antimicrobial studies of an endangered medicinal herb Exacum bicolor Roxb. - Res J Pharm Biol Chem Sci 2: 447-457.

[41] Pellati, F., Brighenti, V., Sperlea, J., Marchetti, L., Bertelli, D., Benvenuti, S. (2018): New methods for the comprehensive analysis of bioactive compounds in Cannabis sativa L. (hemp). - Molecules 23: 2639.

[42] Pin, K. Y., Chuah, T. G., Rashih, A. A., Law, C. L., Rasadah, M. A., Choong, T. S. Y. (2009): Drying of betel leaves (Piper betle L.): Quality and drying kinetics. - Drying Technology 27: 149-155.

[43] Pravin, B., Tushar, D., Vijay, P., Kishanchnad, K. (2013): Review on Citrullus colocynthis. - Int. J. Res. Pharm. Chem 3: 46-53.

[44] Rashid, T., Chen, J., McLeod, P. (2013): Toxicity of newly isolated piperideine alkaloids from the red imported fire ant, Solenopsis invicta Buren, against the green peach aphid, Myzus persicae (Sulzer). - Advances in Entomology 1: 20.

[45] Rathanavel, C., Arasu, P. T. (2014): Antioxidant activity, phenol and flavonoid contents of some selected Indian medicinal plants. - Int. J. Curr. Microbiol. App. Sci 3: 830-838.

[46] Rizvi, T. S., Mabood, F., Ali, L., Al $\square$ Broumi, M., Al Rabani, H. K. M., Hussain, J., Jabeen, F., Manzoor, S., Al $\square$ Harrasi, A. (2018): Application of NIR spectroscopy coupled with PLS regression for quantification of total polyphenol contents from the fruit and aerial parts of Citrullus colocynthis. - Phytochemical Analysis 29: 16-22.

[47] Salama, H. M., Al Rabiah, H. K. (2015): Physiological effects of allelopathic activity of Citrullus colocynthis on Vicia faba and Hordeum vulgare. - European Journal of Biological Research 5: 25-35.

[48] Satyal, P., Setzer, W. N. (2014): Chemotyping and determination of antimicrobial, insecticidal, and cytotoxic properties of wild-grown Cannabis sativa from Nepal. Journal of Medicinally Active Plants 3: 9-16.

[49] Seenivasan, S. P., Jayakumar, M., Raja, N., Ignacimuthu, S. (2004): Effect of bitter apple, Citrullus colocynthis (L.) Schrad seed extracts against pulse beetle, Callosobruchus maculatus Fab. (Coleoptera: Bruchidae). - Entomon-Trivandrum 29: 81-84.

[50] Senguttuvan, J., Paulsamy, S., Karthika, K. (2014): Phytochemical analysis and evaluation of leaf and root parts of the medicinal herb, Hypochaeris radicata L. for in vitro antioxidant activities. - Asian Pacific Journal of Tropical Biomedicine 4: S359S367.

[51] Shi, C., Karim, S., Wang, C., Zhao, M., Murtaza, G. (2014): A review on antidiabetic activity of Citrullus colocynthis Schrad. - Acta Pol Pharm 71: 363-367.

[52] Siddiqui, A. A., Ali, M., 1997. Practical Pharmaceutical Chemistry. - CBS Publishers \& Distributors., Delhi.

[53] Siddiqui, S., Verma, A., Rather, A. A., Jabeen, F., Meghvansi, M. K. (2009): Preliminary phytochemicals analysis of some important medicinal and aromatic plants. - Advances in Biological Research 3: 188-195.

[54] Singh, R., Singh, S., Kumar, S., Arora, S. (2007): Evaluation of antioxidant potential of ethyl acetate extract/fractions of Acacia auriculiformis A. Cunn. - Food and Chemical Toxicology 45: 1216-1223.

[55] Singh, S. (2010): Phytochemical investigation of Sonchus oleraceus leaves and Citrullus colocynth root. - Journal of Herbal Medicine and Toxicology 4: 159-162. 
[56] Soam, P. S., Singh, T., Vijayvergia, R. (2013): Citrullus colocynthis (LINN.) and luffa acutangula (L.) roxb, schrad. source of bioinsecticides and their contribution in managing climate change. - IJABPT 4: 7-9.

[57] Sofowora, A. (1993): Medicinal Plants and Traditional Medicine in Africa. - Spectrum Books, Ibadan, Nigeria.

[58] Tawfik, K., Al-Barazi, M., Bashir, M., Al-Marzouq, W., Al-Soufi, R., Kharsa, H. (2015): A comparative study of antioxidant activities of ziziphus and colocynth from Saudi Arabia deserts and proposed pharmaceutical products. - International Research Journal of Pharmaceutical and Applied Sciences 5: 08-13.

[59] Trease, G. E., Evans, W. C. (2003): Pharmacognosy. - Saunders, London, pp. 479-480.

[60] Uma, C., Sekar, K. G. (2014): Phytochemical analysis of a folklore medicinal plant Citrullus colocynthis L (bitter apple). - Journal of Pharmacognosy and Phytochemistry 2.

[61] Vasu, S. S., Davidson, D. F., Hong, Z., Vasudevan, V., Hanson, R. K. (2009): nDodecane oxidation at high-pressures: measurements of ignition delay times and $\mathrm{OH}$ concentration time-histories. - Proceedings of the Combustion Institute 32: 173-180.

[62] Waiganjo, N., Ochanda, H., Yole, D. (2013): Phytochemical analysis of the selected five plant extracts. - Chemistry and Materials Research 3: 12-17.

[63] Wasylikowa, K., Van der Veen, M. (2004): An archaeobotanical contribution to the history of watermelon, Citrullus lanatus (Thunb.) Matsum. \& Nakai (syn. C. vulgaris Schrad.). - Vegetation History and Archaeobotany 13: 213-217.

[64] Wells, J. B., Christiansen, M. H., Race, D. S., Acheson, D. J., MacDonald, M. C. (2009): Experience and sentence processing: statistical learning and relative clause comprehension. - Cognitive Psychology 58: 250-271.

[65] Yu, L., Perret, J., Harris, M., Wilson, J., Haley, S. (2003): Antioxidant properties of bran extracts from "Akron" wheat grown at different locations. - Journal of Agricultural and Food Chemistry 51: 1566-1570.

[66] Zhao, H., Fan, W., Dong, J., Lu, J., Chen, J., Shan, L., Lin, Y., Kong, W. (2008): Evaluation of antioxidant activities and total phenolic contents of typical malting barley varieties. - Food Chemistry 107: 296-304. 